\title{
Echocardiographic features of bioprosthetic valve endocarditis
}

\author{
SEIKI NAGATA, YUNG-DAE PARK, KAZUTAKA NAGAE, SHINTARO BEPPU, KOHEI \\ KAWAZOE, TSUYOSHI FUJITA, HIROSHI SAKAKIBARA, YASUHARU NIMURA \\ From The National Cardiovascular Centre, Department of Medicine, Division of Cardiology, Cardiac Surgery, and \\ Research Institute, Osaka, fapan
}

SUMMARY Abnormal echocardiographic findings in seven cases of bioprosthetic valve endocarditis were confirmed in six at operation. The echocardiograms showed three cases with thickening and increased echo intensity (group 1) and four (group 2) in which vegetations were seen initially without either of the two features in group 1. Two patients in group 1 had vegetations, the causative organism being a streptococcus. Staphylococcus epidermidis was the causative organism in three of the four cases in group 2; in two of these rapidly growing vegetations were detected. The large vegetations obstructed the ostium of the bioprosthetic valve. Thus if vegetations are detected in cases in which staphylococci are the causative bacteria surgery should be performed as soon as possible. In patients who develop a fever after bioprosthetic valve replacement and especially in those with evident bacteraemia echocardiography should be repeated frequently so that lesions may be detected early.

The number of patients in whom bioprosthetic valves are used is increasing, and endocarditis subsequently remains a problem. Bioprosthetic valves show a higher incidence of leaflet damage at the time of infection than mechanical valves. We report the echocardiographic features of bioprosthetic valve endocarditis in nine patients.

\section{Patients and methods}

Nine patients who underwent valve replacement with bioprosthetic valves (Hancock and Ionescu-Shiley valves) between August 1977 and December 1982 and were suspected of having infective endocarditis because of fever and positive blood cultures were studied. Eight patients underwent echocardiography; one case (case 9) did not.

The echocardiograph used was the Toshiba model SSH-11A.

Requests for reprints to Dr Seiki Nagata, Division of Cardiology, Department of Medicine, National Cardiovascular Centre, Fujishirodai 5-125, Osaka 565, Japan.

\section{Results}

Seven of the eight cases echoed showed abnormal findings.

\section{GROUP 1}

In three cases (cases 2, 3, and 7) valve thickening and increased echo intensity were detected by echocardiography. In one case the inflammation resolved, although the valve thickening remained, in one the vegetations appeared later, and in one there was both valve thickening and an accumulation of vegetations at the initial examination. The causative organisms in all three cases were streptococci (Str faecalis in two, Streptococcus viridans in one).

\section{GROUP 2}

In four cases vegetations were detected at presentation. The causative organism was $S$ epidermidis in three of these; one was infected with Str viridans. There was a rapid growth of the vegetations in two (cases 1 and 4) of the first three cases.

An echocardiogram from case 1 on the tenth day after the onset of fever showed a soft abnormal echo inside the Ionescu-Shiley valve (Fig. 1a). After four days, the echo had notably increased, and the ostium of the mitral valve was almost completely obstructed (Fig. 1b). Because of severe dyspnoea and hypoten- 
Table Clinical data and surgical and echocardiographic findings in nine patients with bioprosthetic valve endocarditis

\begin{tabular}{|c|c|c|c|c|c|c|c|c|c|c|c|c|}
\hline \multirow{2}{*}{$\begin{array}{l}\text { Case } \\
\text { No }\end{array}$} & \multirow{2}{*}{$\begin{array}{l}\text { Age } \\
\text { (yr) } \\
\text { and } \\
\text { sex }\end{array}$} & \multirow{2}{*}{$\begin{array}{l}\text { Underlying } \\
\text { disease }\end{array}$} & \multirow{2}{*}{$\begin{array}{l}\text { Valve } \\
\text { site }\end{array}$} & \multirow{2}{*}{$\begin{array}{l}\text { Months since } \\
\text { initial valve }\end{array}$} & \multirow{2}{*}{$\begin{array}{l}\text { Cause of } \\
\text { fever }\end{array}$} & \multirow{2}{*}{$\begin{array}{l}\text { Micro- } \\
\text { organism }\end{array}$} & \multicolumn{2}{|l|}{ Surgery } & \multicolumn{4}{|c|}{ Echocardiographic findings } \\
\hline & & & & & & & $\begin{array}{l}\text { Reop- } \\
\text { eration }\end{array}$ & $\begin{array}{l}\text { Findings } \\
\text { and } \\
\text { outcome }\end{array}$ & Vegetation & $\begin{array}{l}\text { Increased } \\
\text { echo } \\
\text { intensity }\end{array}$ & $\begin{array}{l}\text { Valve } \\
\text { thick- } \\
\text { ening }\end{array}$ & $\begin{array}{l}\text { Time fromo } \\
\text { fever to } \\
\text { detection of } \\
\text { abnormalitg } \\
\text { (d) }\end{array}$ \\
\hline 1 & $48 \mathrm{~F}$ & $\begin{array}{l}\text { HCM, ruptured } \\
\text { chordae } \\
\text { tendineae }\end{array}$ & $M^{\star}$ & 1 & Unknown & $S$ epidermidis & + & $\begin{array}{l}\text { Died, no } \\
\text { embolism }\end{array}$ & $\begin{array}{l}\text { Rapidly } \\
\text { increased }\end{array}$ & $1^{-}$ & - & 10 \\
\hline 2 & $54 \mathrm{~F}$ & MSR & $M^{\star}$ & $\begin{array}{l}\text { Immediately } \\
\text { after surgery }\end{array}$ & & Str faecalis & - & $\begin{array}{l}\text { Alive, no } \\
\text { embolism }\end{array}$ & - & + & + & 56 \\
\hline 3 & $64 M$ & MVP & $\mathbf{M}^{\star}$ & $\begin{array}{l}\text { Immediately } \\
\text { after surgery }\end{array}$ & & Str faecalis & + & $\begin{array}{l}\text { Alive, no } \\
\text { embolism }\end{array}$ & + & - & + & 23 \\
\hline 4 & $36 \mathrm{~F}$ & MSR & $\mathbf{M}+$ & 2 & Unknown & $S$ epidermidis & + & $\begin{array}{l}\text { Alive, } \\
\text { embolism }\end{array}$ & $\begin{array}{l}\text { Rapidly } \\
\text { increased }\end{array}$ & - & - & 28 \\
\hline 5 & $40 \mathrm{~F}$ & MSR & $\mathbf{M}+$ & 35 & URTI & Str viridans & + & $\begin{array}{l}\text { Alive, no } \\
\text { embolism }\end{array}$ & + & - & - & 35 \\
\hline 6 & $36 M$ & $\begin{array}{l}\text { VSD, ruptured } \\
\text { aneurysm of } \\
\text { sinus of Valsalva }\end{array}$ & $\mathbf{A}^{\star}$ & 5 & URTI & $S$ epidermidis & + & $\begin{array}{l}\text { Aortic ring } \\
\text { abscess, alive } \\
\text { embolism }\end{array}$ & + & - & - & 23 \\
\hline 7 & $59 \mathrm{~F}$ & Aortitis, AR & $\mathbf{A}^{\star}$ & 18 & Unknown & Str viridans & + & $\begin{array}{l}\text { Aortic ring } \\
\text { granulation, } \\
\text { alive, no } \\
\text { embolism }\end{array}$ & + & - & + & 13 \\
\hline 8 & $45 M$ & MS & $\mathbf{M} \boldsymbol{\dagger}$ & $\begin{array}{l}\text { Immediately } \\
\text { after surgery }\end{array}$ & & $S$ epidermidis & + & $\begin{array}{l}\text { Alive, no } \\
\text { embolism }\end{array}$ & - & - & - & \\
\hline 9 & $55 \mathrm{~F}$ & $\begin{array}{l}\text { MSR } \\
\text { ASR }\end{array}$ & $\begin{array}{l}M \\
\text { and } A^{\star}\end{array}$ & $\begin{array}{l}\text { Immediately } \\
\text { after surgery }\end{array}$ & & Candida sp & - & $\begin{array}{l}\text { Died, } \\
\text { necropsy, no } \\
\text { embolism }\end{array}$ & & Not done & & \\
\hline
\end{tabular}

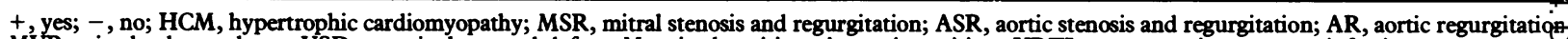
MVP, mitral valve prolapse; VSD, ventricular septal defect; $M$, mitral position; A, aortic position; URTI, upper respiratory tract infection. $\star$ Ionescu-Shiley valve. †Hancock valve.
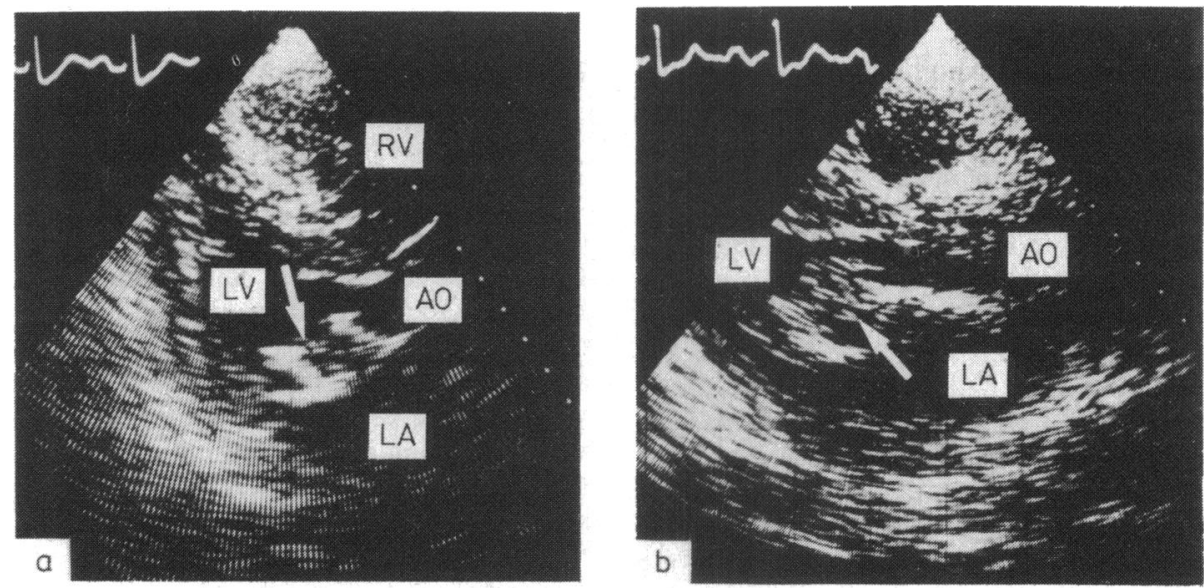

Fig. 1 Echocardiograms in patient (case 1) with rapidly growing bioprosthetic valve vegetations showing (a) an abnormal mass-like echo in an Ionescu-Shiley valve (arrow), and (b) increased size of the echo four days later (arrow). AO, aorta; $L A$, left atrium; $L V$, left ventricle; $R V$, right ventricle.

sion an emergency operation was performed on the same day and the ostium of the Ionescu-Shiley valve was found to be almost completely obstructed by massive vegetations (Fig. 2), accounting for the abnormal echo findings preoperatively.

In case 4 , the echocardiagram was obtained on the twenty eighth day after the onset of fever. An accumulation of vegetations was seen in the posteromedial leaflet (Fig. 3a). These appeared larger three days later (Fig. 3b), and their presence was confirmed at operation.

\section{Discussion}

The diagnosis of infective endocarditis on artificial valves has always been difficult, and many patients die 


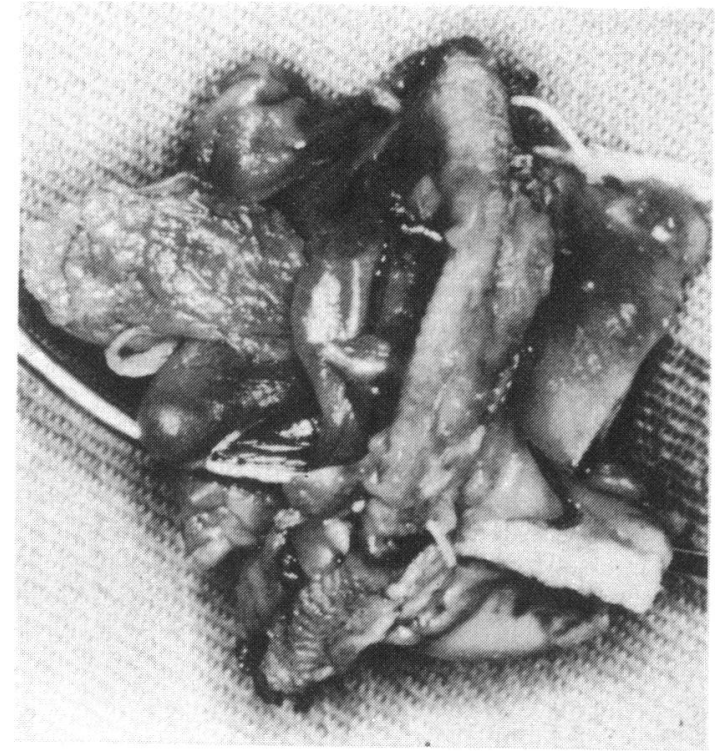

Fig. 2 Massive vegetation obstructing the ostium of the Ionescu-Shiley valve which was removed at operation.

before the lesions are detected. The findings in this study show that abnormal echocardiographic findings may be found in bioprosthetic valve infection at an early stage. Echocardiography should be performed frequently in patients with bioprosthetic valves who develop fever of unknown cause and especially in those with bacteraemia.

The diagnosis in our nine patients was confirmed macroscopically at operation or necropsy or from echocardiograms performed during the study. Abnormal microscopic findings have been reported in patients with bacteraemia with biopsthetic valves without accompanying macroscopic changes, ${ }^{1}$ but valve dysfunction occurred later when the latter appeared. In seven of our eight cases in which echocardiography was performed macroscopic changes were indeed found, and the technique appears to be valuable. In case 9 echocardiography was not performed, but in case 8 , although it was performed, no abnormal findings were seen. Nevertheless, at operation massive vegetations were found attached to the Hancock valve in the mitral position. Since the last echocardiograms were performed seven days before operation it seems likely that the vegetations grew in this period, although they may have been present, if not seen, at echo.

The abnormal echocardiographic findings obtained in the seven cases were, firstly, valve thickening and increased echo intensity and, secondly, vegetations seen initially without either of these features. The bacteria detected in all the former cases were strep-
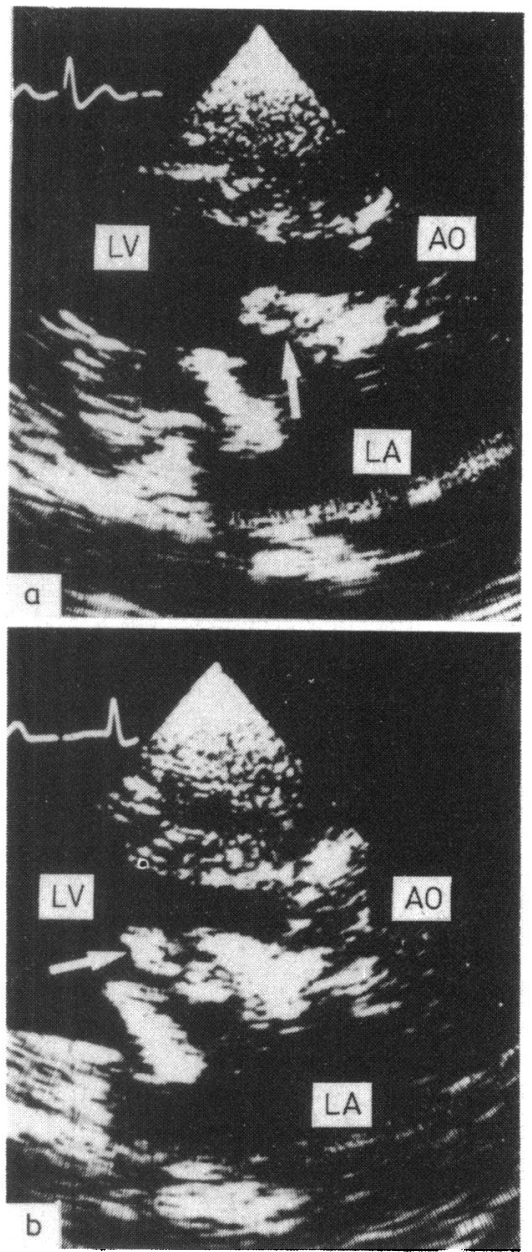

Fig. 3 Echocardiogram in patient (case 4) with rapidly growing valve vegetation showing (a) an abnormal mass-like echo, and $(b)$ increased size of the echo three days later (arrow). $L V$, left ventricle; $L A$, left atrium; $A O$, aorta.

tococci. $S$ epidermidis was the causative bacteria in three of the latter four cases. There was a rapid increase in the size of the vegetations in two of these three cases. The large vegetations obstructed the ostium of the bioprosthetic valves and affected the functioning of the valve. It is known that staphylococci are strongly invasive organisms ${ }^{12}$ and thus if vegetations are detected when these are the cause of endocarditis surgery should be performed as soon as possible. ${ }^{2}$

Endocarditis affects the leaflets of bioprosthetic valves more often than the aortic root or mitral ring, ${ }^{3}$ although cases have been reported in which paravalve abscesses have been undetected. ${ }^{4}{ }^{5}$ In our study, vegetations were limited to the leaflets in five of the seven 
patients.

Detection of endocarditis should be early for survival may depend on this, and repeated echocardiography in suspected cases is vital. Although others have previously reported the echocardiographic findings in bioprosthetic endocarditis, ${ }^{5-9}$ the correlation with the clinical course and the causative bacteria which we have described has not been recorded.

\section{References}

1 Wilson WR, Danielson GK, Giuliani ER, Geraci JE. Prosthetic valve endocarditis. Mayo Clin Proc 1982; 57: 155-61.

2 Dinubile MJ. Surgery in active endocarditis. Ann Intern Med 1982; 96: 650-9.

3 Ferrans VJ, Boyce SW, Billingham ME, Spray TL, Roberts WC. Infection of glutaraldehyde-reserved por- cine valve heterografts. Am $\mathcal{F}$ Cardiol 1979; 43: 1123-36.

4 Nakamura K, Suzuki S, Satomi G, Hayashi H, Hirosawa $\mathrm{K}$. Detection of mitral ring abscess by two-dimensional echocardiography. Circulation 1982; 65: 816-9.

5 Wong CM, Oldershaw P, Gibson DG. Echocardiographic demonstration of aortic root abscess after infective endocarditis. Br Heart $\mathcal{F}$ 1981; 46: 584-6.

6 Schapira JN, Martin RP, Fowles RE, et al. Two dimensional echocardiographic assessment of patients with bioprosthetic valves. Am f Cardiol 1979; 43: 510-9.

7 Martin RP, Meltzer RS, Chia BL, Stinson EB, Rakowski H, Popp RL. Clinical utility of two-dimensional echocardiography in infective endocarditis. Am $\mathcal{f}$ Cardiol 1980; 46: 379-85.

8 Strasberg B, Kanakis C, Eckner F, Rosen K. Echocardiographic demonstration of porcine mitral valve vegetation and dehiscence. Eur $\mathcal{F}$ Cardiol 1980; 12: 41-5.

9 Alam M, Madrazo AC, Magilligan DJ, Goldstein S. M mode and two dimensional echocardiographic features of porcine valve dysfunction. Am $\mathcal{F}$ Cardiol 1979; 43: 502-9. 